\title{
Modeling of Drying and Adsorption Isotherms of the Fish Feed
}

\author{
Ana Claudia Werner Pacheco, Gianini Regina Luz, Paulo Eduardo Polon, Luiz Mário de \\ Matos Jorge and Paulo Roberto Paraíso \\ Departamento de Engenharia Química; Universidade Estadual de Maringá; Av. Colombo, 5790; 87020-900; \\ Maringá - PR - Brasil
}

\begin{abstract}
The aim of this work was to study the drying curves and equilibrium isotherms of extruded fish feed. The drying curves were determined at air temperatures of 50,60, 70 and $80^{\circ} \mathrm{C}$ and airflow velocities of $1.5,2.5$ and $3.5 \mathrm{~m} / \mathrm{s}$ ). The equilibrium isotherms of relative humidity of air were obtained between 10 and $80 \%$ at $30,40,50$, and $70^{\circ} \mathrm{C}$. The experimental data were fitted for non-linear regression by using STATISTICA ${ }^{\circledR}$ to the models reported in the literature. The results showed that the drying curves and the equilibrium isotherms were significantly influenced by variations of the air temperature in a similar way to solid materials as described in the literature. The statistical results for models of Page and Peleg showed that the fitting of the experimental drying curve and isotherm data were satisfactory.
\end{abstract}

Key words: extruded fish feed, adsorption isotherms, equilibrium moisture

\section{INTRODUCTION}

Aquaculture is becoming an important productive component of the food safety in animal protein. It has been well developed in Brazil and in the world in the last decades. Factors such as the decrease of the natural fishing, environmental restrictions, governmental incentives, and medical recommendations for a healthier diet have contributed to an increase in the demand of fish meat. The success of the aquaculture depends on the quality and final product cost to the consumers. According to Magliano (2007), the feed cost may correspond up to $70 \%$ of the fish meat production cost of a fish breeding station. With an aim to make aquaculture an economically and environmentally sustainable activity, attempts have been made to develop the fish feed formulation of low cost with minimum environmental impact (Kubitza, 1997; El-Sayed, 1999; Faria et al., 2001a and 2001b; Al-Ruqaie, 2008). Other studies have been conducted to improve the nutritional and sensorial aspects of the feeds aiming the appropriate consumption and a greater gain of weight for animals (Kubitza, 1995; Souza and Hayashi, 2003; Teixeira et al., 2007). Sussel (2008) reported that the large increase in the fish breeding was due to the development of pelletized feed and later of extruded feed. The high temperature and pressure conditions are used in extruded feed to promote the suitable physicalchemical modifications in the ingredients and improve the feeding efficiency of fishes. Furthermore, the extruded feed can float on the

*Author for correspondence: paulo@deq.uem.br 
water, reducing the nutrient leaching causing environmental impact (FAPEAM, 2009; Botaro, 2007).

After the extrusion, the feed is dried to a moisture level that prevents the proliferation of microorganisms to ensure its quality during handling and transportation. Drying requires large amount of energy and may increase the production costs, especially if the equipment operating conditions are not appropriate. Nevertheless, drying must be optimized for the production of a good quality product at an accessible cost to the consumer. This requires knowledge of the drying kinetics of feed, because it influences the design, operation, and efficient control of the dryer.

The drying kinetics describes the moisture variation profile of the material with time. Models that represent the drying curves have been proposed based on the variables that may interfere on product drying. According to Brooker et al. (1992), empirical and semi-empirical models are the best options to estimate the moisture variation of materials. Some examples of application of these models were identified in the analyses of drying of urucum (Bixa orellana L.) using the Lewis, Page, Thompson, Overhults, Brooker, Henderson and Motta Lima (Guedes and Faria, 2000), of beans (Phaseolus vulgaris L.) using the correlations of Wangh and Singh, Verna, Thompson, Page, Midilli, Logarithmic, Henderson and Pabis, Henderson and modified Pabis, twoterm exponential (Corrêa et al., 2007) and of fertilizers using the Lewis, Brooker, Page, Overhults, Henderson and Henderson (Arruda, 2008) models. The utilization of these models requires the knowledge of the drying data and system operation conditions. When these data are not available, dimensionless moisture data of the product are experimentally obtained as a function of time.

The concern with feed quality and cost reduction is fundamental for the production and commercialization of the feed. Therefore, both the feed producer and consumer need to know the adsorption behavior in several ambient conditions to prevent losses during the storage and supply of the feed of acceptable quality to the market.

The moisture adsorption by the product on the shelf or after opening its package is related to the equilibrium moisture defined as the amount of corresponding moisture to the equilibrium between the water vapor pressure in the material and in the ambient. The correlation between the equilibrium moisture and water activity at a given temperature is called equilibrium isotherm (Karathanos et al., 1996). The equilibrium isotherms of certain products may be determined by using experimental data or estimated data by non-linear models found in the literature. As such, the BET, $\mathrm{GAB}$, and Oswin models are the most common ones for accuracy and large application (Fadini et al., 2006). Recently, these and other models have been investigated by Gomes et al. (2002) in a study of adsorptions isotherms of acerola pulp applying BET, GAB, Oswin, and Smith, by Ascheri et al. (2007) in a study of the moisture adsorption of pre-gelatinized jabuticaba bagasse and rice applying Chung-Pfost, Halsey, GAB, BET, Oswin and modified Henderson, and by Alexandre et al. (2007) in the study of the adsorption isotherms of powdered pitanga applying GAB, Oswin, and Peleg correlations. However, the use of these models depends on the knowledge of the water activity or relative humidity of air, the drying temperature, and material-specific parameters. In the absence of these data, the equilibrium moisture data must be obtained in laboratory by gravimetry or hygrometry (Barrozo et al., 2000; Mujumdar, 1987).

Tithed aim of this work was to investigate the drying kinetics and adsorption moisture, and their fittings for mathematical models as tools for the design and simulation of industrial feed dryers.

\section{MATERIALS AND METHODS}

The feed samples were provided by a company in northern Paraná with spherical pellets (diameter 6 to $8 \mathrm{~mm}$; initial moisture 0.30 (d.b.) The moisture was determined by drying at $105^{\circ} \mathrm{C} \pm 2^{\circ} \mathrm{C}$ for 24 h.

\section{Drying kinetics data of feed}

The drying data of the feed were obtained by using a bench scale convective dryer, as shown in Figure 1. 


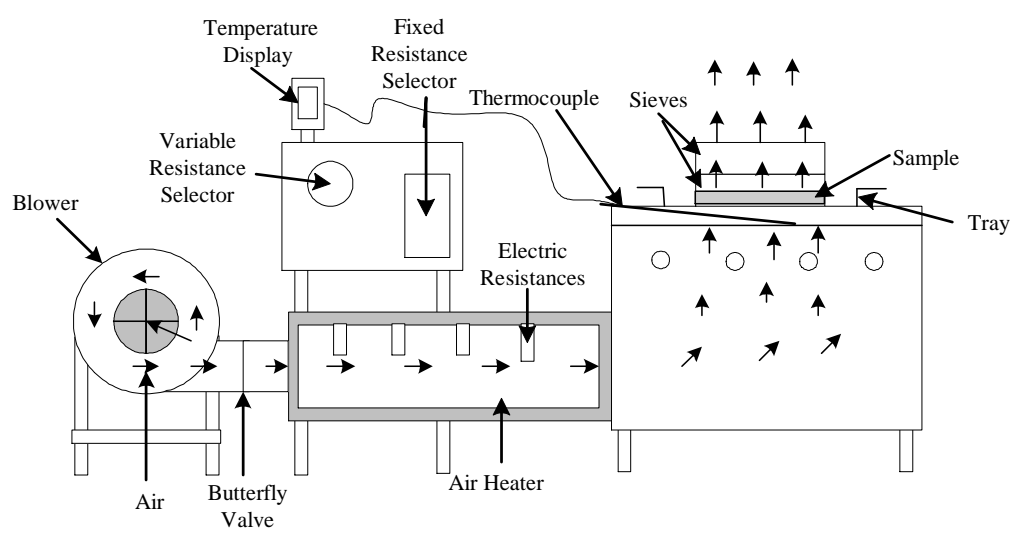

Figure 1 - Convective dryer scheme.

In this dryer, each assay was carried out with approximately $80 \mathrm{~g}$ of feed, amount sufficient to cover the drying bed constituted by two sieves with meshes of 200 and 270 . Thermocouples were distributed under the dryer tray. The flow and air temperature were monitored by using an anemometer and a psychrometer, respectively. The stabilized drying conditions were registered with the ambient air data. Afterwards, the sieves with sample were set on the dryer tray and the drying was started. The sample-sieves set was weighed in an analytical balance every $30 \mathrm{~s}$ during the first 6 min due to the high evaporation in the beginning. Later, data were collected every minute until it completed the first hour of processing. In the next hour, the data were collected every $2 \mathrm{~min}$, due to the low moisture variation in this period. The drying conditions were reregistered with the ambient air data. At the end, the feed dry mass was determined in the oven at $105^{\circ} \mathrm{C} \pm 2{ }^{\circ} \mathrm{C}$ for $24 \mathrm{~h}$.

Equation 1 was used to determine the solid moisture profile.

$\mathrm{X}_{\mathrm{s}}=\frac{\mathrm{m}-\mathrm{m}_{\mathrm{ss}}}{\mathrm{m}_{\mathrm{ss}}}$

Where $X_{s}$ is the solid moisture (d.b.), $m$ is the feed mass at each drying time $(\mathrm{g})$ and $\mathrm{m}_{\mathrm{ss}}$ is the feed sample mass in the oven $(\mathrm{g})$.

The drying rate, N, was determined by Equation 2 .

$\mathrm{N}=\frac{\Delta \mathrm{X}_{\mathrm{s}}}{\Delta \mathrm{t}}$
Where $\mathrm{N}$ is drying rate $(1 / \mathrm{s}), \Delta \mathrm{X}_{\mathrm{s}}$ is the variation of the solid moisture (d.b.) and $\Delta \mathrm{t}$ is the time variation.

The previous procedures were repeated at 50, 60, 70 , and $80^{\circ} \mathrm{C}$ under airflow velocities of $1.5,2.5$, and $3.5 \mathrm{~m} / \mathrm{s}$.

The dimensionless moisture ratio of the extruded feed, $M R$, at the different drying conditions was calculated by using Equation 3 .

$$
M R=\frac{X_{s}-X_{e}}{X_{i}-X_{e}}
$$

Where $X_{s}$ is the solid moisture (d.b.), $X_{e}$ is the solid equilibrium moisture (d.b.) and $X_{i}$ is the solid initial moisture (d.b.).

\section{Fitting of the extruded feed drying curves}

The extruded feed drying curves were fitted to the mathematical models of Wang and Singh, Thompson and Page as follow.

- Wang and Singh (Wang and Singh, 1978)

$$
\mathrm{MR}=1+\mathrm{at}+\mathrm{bt}^{2}
$$

- Thompson (Thompson et al., 1968)

$$
\begin{aligned}
& \text { MR }=\exp \left(\left(-\mathrm{a}-\left(\mathrm{a}^{2}+4 \mathrm{bt}\right)^{0,5}\right) / 2 \mathrm{~b}\right) \\
& \quad \quad \text { Page }(\text { Page, 1949) } \\
& \mathrm{MR}=\exp \left(-\mathrm{kt}^{\mathrm{n}}\right)
\end{aligned}
$$

Where $\mathrm{a}, \mathrm{b}, \mathrm{c}, \mathrm{n}$ are model constants, $\mathrm{k}$ is the drying constant, $t$ is the drying time (s), and MR is the dimensionless product moisture ratio. 
The regression analysis was performed using computer software, namely, STATISTICA ${ }^{\circledR}$ version 5.0. Regression work was done based on the Quasi-Newton method and convergence criterion of 0.0001 .

The parameters used to evaluate the curve fittings were the coefficient of determination $\left(\mathrm{R}^{2}\right)$, the relative mean deviation, $\mathrm{P}$, and the estimated error, EE. Values of $\mathrm{P}$ and $\mathrm{EE}$ were calculated by Equations 7 and 8, respectively.

$$
\begin{aligned}
& \mathrm{P}=\frac{100}{\mathrm{n}} \sum_{\mathrm{i}=1}^{\mathrm{n}} \frac{\left|\mathrm{MR}_{\text {exp }}-\mathrm{MR}_{\text {calc }}\right|}{\mathrm{MR}_{\text {exp }}} \\
& \mathrm{EE}=\sqrt{\frac{\sum_{\left(\mathrm{MR}_{\text {exp }}-\mathrm{MR}_{\text {calc }}\right)}^{2}}{\mathrm{DOF}}}
\end{aligned}
$$

Where $\mathrm{MR}_{\text {exp }}$ is the experimental feed moisture ratio, $\mathrm{MR}_{\text {calc }}$ is the calculated feed moisture ration is the number of experimental observations, and DOF is the number of degrees of freedom (number of observations minus the number of observed parameters of the model).

\section{Equilibrium isotherms}

The classical gravimetric method was used to obtain the solid adsorption equilibrium isotherms, as follow.

The feed samples were initially dried in an oven for $24 \mathrm{~h}$ at $105^{\circ} \mathrm{C} \pm 2^{\circ} \mathrm{C}$ to determine the dry mass and guarantee the moisture adsorption by using salt solutions. The samples were stored in basketlike recipients that were weighed empty and with sample in an analytical balance. The determination of the mass of the empty recipient facilitated the weighting of the samples in the following steps. Afterwards, saturated samples were prepared and warmed, resulting relative humidity of air between 10 and $80 \%$, as reported by Arnosti Jr. (1997) for $\mathrm{LiCl}, \mathrm{CH}_{3} \mathrm{CO}_{2} \mathrm{~K}, \mathrm{MgCl}_{2} \cdot 6 \mathrm{H}_{2} \mathrm{O}, \mathrm{NaNO}_{2}, \mathrm{NaCl}$, and $\mathrm{KCl}$. The solutions were prepared in duplicate with the salt and water masses informed by Perry and Chilton (1980). The samples and saline solutions were kept in closed jars to prevent their direct contact as shown in Figure 2.

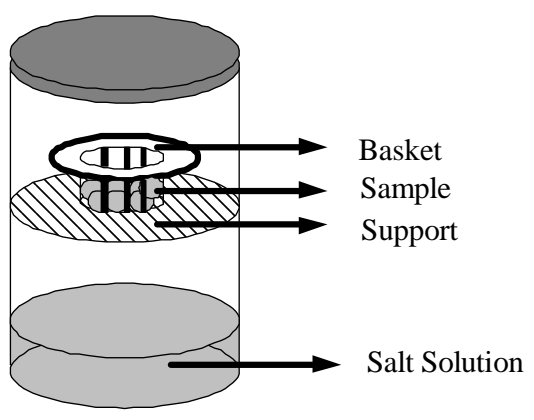

Figure 2 - Experimental jar

After storing the samples and solutions, the jars were kept in the oven at $50^{\circ} \mathrm{C}$. The samples were weighed in the baskets at regular intervals until that the mass was constant, indicating that hygroscopic equilibrium was reached. The equilibrium moisture (d.b.), $X_{e}$, was calculated by Equation (1).

These procedures were repeated for new feed samples at 30,40 , and $70^{\circ} \mathrm{C}$.

\section{Fitting of the equilibrium isotherms}

The extruded feed equilibrium isotherms were fitted to the mathematical models of Peleg, Henderson-Thompson and Keey, as follow.
- Peleg model (Peleg, 1993)

$$
\mathrm{X}_{\mathrm{e}}=\mathrm{aa}_{\mathrm{w}}{ }^{\mathrm{b}}+\mathrm{ca}_{\mathrm{w}}{ }^{\mathrm{d}}
$$

- Henderson -Thompson model (Thompson et al., 1968)

$$
X_{e}=\left\lfloor\frac{\ln \left(1-a_{w}\right)}{-a(T+c)}\right\rfloor^{1 / b}
$$




$$
X_{e}=\frac{a}{1+b T^{3} \ln \left(\frac{1}{a_{w}}\right)}
$$

Where a, b, c, d are model parameters, $a_{w}$ is the water activity, and $\mathrm{T}$ is the feed drying temperature $(\mathrm{K})$.

The regression analysis was performed using computer software STATISTICA ${ }^{\circledR}$ version 5.0. Regression work was done based on the Rosenbrook and Quasi-Newton and convergence criterion of 0.0001 .

The parameters used to evaluate the model fitting were the coefficient of determination, $\mathrm{R}^{2}$, the test $\mathrm{F}, \mathrm{F}$, and the relative mean deviation, P. As such, the test $\mathrm{F}$ was calculated by Equation 12 .

$$
\mathrm{F}=\left(\frac{\left(\mathrm{MR}_{\text {calc }}{ }^{2}\right)_{\text {mean }}}{\left(\mathrm{MR}_{\text {exp }}-\mathrm{MR}_{\text {calc }}\right)_{\text {mean }}^{2}}\right)
$$

\section{RESULTS AND DISCUSSION}

\section{Extruded fish feed drying curves}

Figures 3 and 4 show the solid drying curves at different air temperatures and constant airflow velocity.

The profiles of the feed drying curves shown in Figures 3, 4, and 5 are characteristic of solid materials. It was also observed that the increase of the air temperature resulted in larger sample drying rates, which were less pronounced in the beginning of drying.

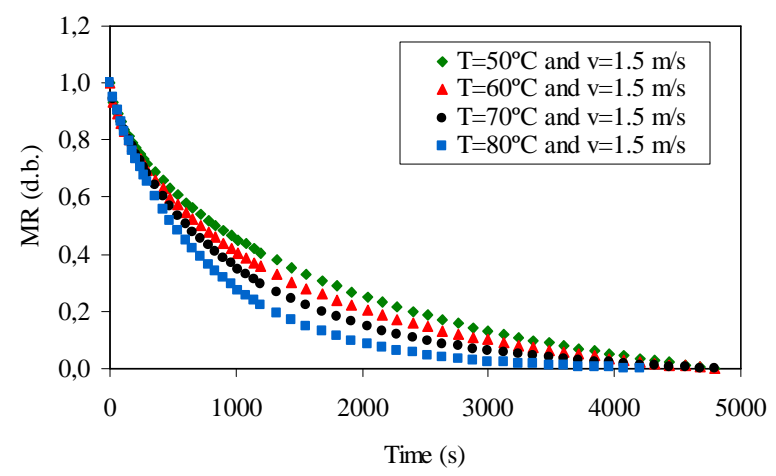

Figure 3 - Influence of air temperature $(\mathrm{v}=1.5 \mathrm{~m} / \mathrm{s})$ on fish feed drying.

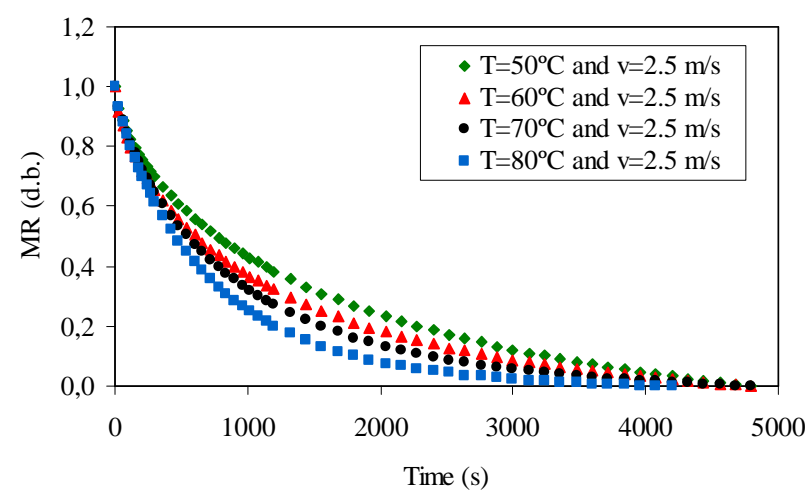

Figure 4 - Influence of air temperature $(v=2.5 \mathrm{~m} / \mathrm{s})$ on fish feed drying. 


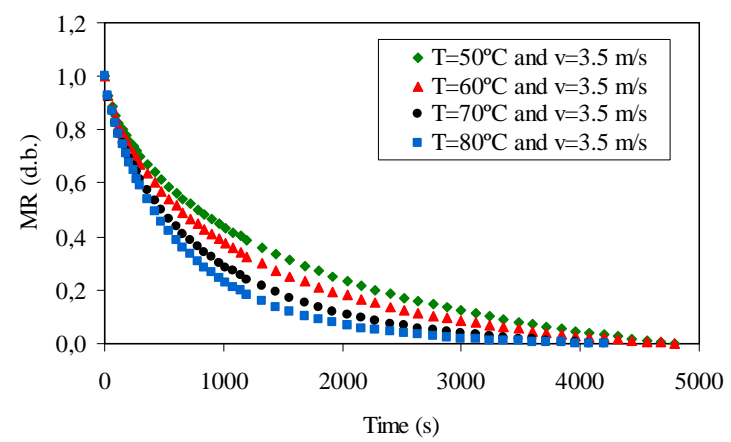

Figure 5 - Influence of air temperature $(v=3.5 \mathrm{~m} / \mathrm{s})$ on fish feed drying.

Figures 6 and 7 show the solid drying curves at different airflows velocities and constant air temperature.

The feed drying curves shown in Figures 6 and 7 were slightly influenced by the airflow velocity and more pronounced at higher temperatures. At $50^{\circ} \mathrm{C}$, the curves practically overlapped, while at $80^{\circ} \mathrm{C}$, the influence of the temperature was more pronounced.

The feed drying curves shown in Figures 3 to 7 were as reported by Mrkic et al. (2007) for the drying of broccoli and by Luz et al. (2009) for the drying of soybean meal.

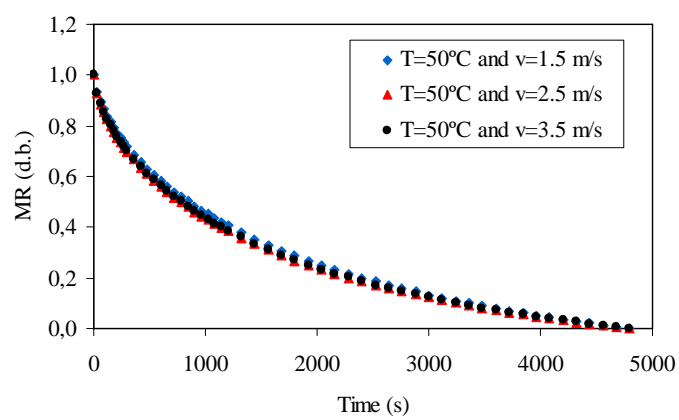

Figure 6 - Influence of airflow velocity $\left(\mathrm{T}=50^{\circ} \mathrm{C}\right)$ on fish feed drying.

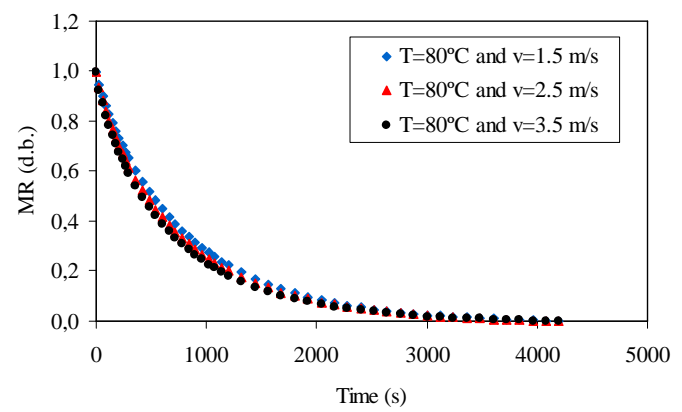

Figure 7 - Influence of airflow velocity $\left(\mathrm{T}=80^{\circ} \mathrm{C}\right)$ on fish feed drying.

Considering the effect of the air temperature and airflow velocity on feed drying, the model parameters of Equations 4 to 6 were estimated and related by statistical parameters $\left(\mathrm{R}^{2}, \mathrm{P}\right.$, and $\left.\mathrm{EE}\right)$ that were analyzed for the different drying conditions.

As observed in Table 1, the Thompson and Page models presented satisfactory results with the best 
statistical fitting values. However, the Page model stands out for its greatest $\mathrm{R}^{2}$ and lowest $\mathrm{P}$ and $\mathrm{EE}$ values, demonstrating to be the most suitable one to estimate the extruded feed drying curve. The fitting results of this model are shown in Figures 8, 9 and 10.

Table 1 - Estimated parameters of the models of the drying curves of extruded fish feed.

\begin{tabular}{|c|c|c|c|c|c|c|c|}
\hline \multirow[t]{2}{*}{ Models } & \multicolumn{2}{|c|}{ Drying conditions } & \multicolumn{2}{|c|}{ Model parameters } & \multicolumn{3}{|c|}{ Fitting parameters } \\
\hline & $\mathbf{T}\left({ }^{\circ} \mathbf{C}\right)$ & $\mathbf{v}(\mathbf{m} / \mathbf{s})$ & $a$ & $b$ & $R^{2}$ & $P$ & $E \boldsymbol{E}$ \\
\hline Wang and Singh & 50 & 1.5 & -0.00054 & $7.47121 .10^{-8}$ & 0.920 & 69.72 & 0.0844 \\
\hline Wang and Singh & 50 & 2.5 & -0.00056 & $7.94652 .10^{-8}$ & 0.901 & 84.42 & 0.0929 \\
\hline Wang and Singh & 50 & 3.5 & -0.00056 & $7.87756 .10^{-8}$ & 0.905 & 76.85 & 0.0913 \\
\hline Wang and Singh & 60 & 1.5 & -0.00059 & $8.48285 .10^{-8}$ & 0.905 & 97.48 & 0.0935 \\
\hline Wang and Singh & 60 & 2.5 & -0.00062 & $9.24961 .10^{-8}$ & 0.854 & 137.17 & 0.1116 \\
\hline Wang and Singh & 60 & 3.5 & -0.00061 & $9.12356 .10^{-8}$ & 0.879 & 154.08 & 0.1039 \\
\hline Wang and Singh & 70 & 1.5 & -0.00064 & $9.66913 .10^{-8}$ & 0.896 & 214.48 & 0.1000 \\
\hline Wang and Singh & 70 & 2.5 & -0.00066 & $1.02270 .10^{-7}$ & 0.857 & 292.25 & 0.1161 \\
\hline Wang and Singh & 70 & 3.5 & -0.00075 & $1.33356 .10^{-7}$ & 0.848 & 250.35 & 0.1105 \\
\hline Wang and Singh & 80 & 1.5 & -0.00076 & $1.35585 .10^{-7}$ & 0.899 & 420.71 & 0.1012 \\
\hline Wang and Singh & 80 & 2.5 & -0.00079 & $1.42869 .10^{-7}$ & 0.855 & 473.64 & 0.1171 \\
\hline \multirow[t]{2}{*}{ Wang and Singh } & 80 & 3.5 & -0.00081 & $1.48412 .10^{-7}$ & 0.821 & 594.13 & 0.1280 \\
\hline & $\mathbf{T}\left({ }^{\circ} \mathbf{C}\right)$ & $\mathrm{v}(\mathrm{m} / \mathrm{s})$ & $a$ & $b$ & $R^{2}$ & $\boldsymbol{P}$ & $E \boldsymbol{E}$ \\
\hline Thompson & 50 & 1.5 & -24.0895 & $1.57090 .10^{-1}$ & 0.989 & 41.25 & 0.0317 \\
\hline Thompson & 50 & 2.5 & -19.2253 & $1.50518 .10^{-1}$ & 0.989 & 45.15 & 0.0311 \\
\hline Thompson & 50 & 3.5 & -20.2168 & $1.52220 .10^{-1}$ & 0.989 & 44.41 & 0.0310 \\
\hline Thompson & 60 & 1.5 & -23.0511 & $1.65142 .10^{-1}$ & 0.993 & 46.07 & 0.0251 \\
\hline Thompson & 60 & 2.5 & -14.7191 & $1.51697 .10^{-1}$ & 0.992 & 54.45 & 0.0256 \\
\hline Thompson & 60 & 3.5 & -18.9435 & $1.61734 .10^{-1}$ & 0.994 & 51.60 & 0.0236 \\
\hline Thompson & 70 & 1.5 & -30.0880 & $1.96186 .10^{-1}$ & 0.997 & 50.32 & 0.0158 \\
\hline Thompson & 70 & 2.5 & -21.9348 & $1.82583 .10^{-1}$ & 0.997 & 58.75 & 0.0165 \\
\hline Thompson & 70 & 3.5 & -18.2384 & $1.80992 .10^{-1}$ & 0.996 & 55.22 & 0.0182 \\
\hline Thompson & 80 & 1.5 & -47.6436 & $2.61564 .10^{-1}$ & 0.999 & 43.58 & 0.0089 \\
\hline Thompson & 80 & 2.5 & -29.5501 & $2.24693 .10^{-1}$ & 0.999 & 56.00 & 0.0109 \\
\hline \multirow[t]{2}{*}{ Thompson } & 80 & 3.5 & -24.7011 & $2.17210 .10^{-1}$ & 0.999 & 63.46 & 0.0111 \\
\hline & $\mathbf{T}\left({ }^{\circ} \mathbf{C}\right)$ & $\mathrm{v}(\mathrm{m} / \mathrm{s})$ & $k$ & $n$ & $R^{2}$ & $\boldsymbol{P}$ & $E \boldsymbol{E}$ \\
\hline Page & 50 & 1.5 & 0.00296 & $8.14313 .10^{-1}$ & 0.994 & 34.97 & 0.0226 \\
\hline Page & 50 & 2.5 & 0.00372 & $7.90533 .10^{-1}$ & 0.995 & 36.34 & 0.0213 \\
\hline Page & 50 & 3.5 & 0.00353 & $7.96408 .10^{-1}$ & 0.995 & 36.09 & 0.0213 \\
\hline Page & 60 & 1.5 & 0.00329 & $8.15995 .10^{-1}$ & 0.997 & 35.95 & 0.0160 \\
\hline Page & 60 & 2.5 & 0.00524 & $7.63735 .10^{-1}$ & 0.997 & 38.96 & 0.0152 \\
\hline Page & 60 & 3.5 & 0.00413 & $7.95080 .10^{-1}$ & 0.998 & 37.45 & 0.0138 \\
\hline Page & 70 & 1.5 & 0.00287 & $8.55210 .10^{-1}$ & 0.999 & 35.55 & 0.0081 \\
\hline Page & 70 & 2.5 & 0.00397 & $8.19738 .10^{-1}$ & 0.999 & 37.45 & 0.0075 \\
\hline Page & 70 & 3.5 & 0.00491 & $8.02480 .10^{-1}$ & 0.999 & 35.11 & 0.0087 \\
\hline Page & 80 & 1.5 & 0.00232 & $9.13796 .10^{-1}$ & 0.999 & 29.84 & 0.0041 \\
\hline Page & 80 & 2.5 & 0.00344 & $8.67847 .10^{-1}$ & 0.999 & 32.02 & 0.0040 \\
\hline Page & 80 & 3.5 & 0.00412 & $8.50077 .10^{-1}$ & 0.999 & 32.29 & 0.0035 \\
\hline
\end{tabular}

The Page model has been largely used to represent the drying curves of food and agricultural product, as shown in Figures 8, 9 and 10. These studies include the drying of urucum by Guedes and Faria
(2000), green malt by Santosi et al. (2001), popcorn and barley by Corrêa et al. (2001) and beans by Corrêa et al. (2007). 


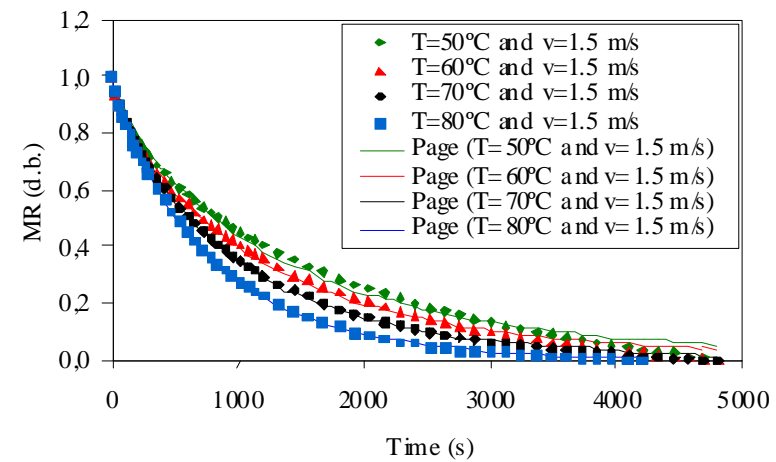

Figure 8 - Experimental and predicted dimensionless moisture of fish feed drying at airflow velocity of $1.5 \mathrm{~m} / \mathrm{s}$.

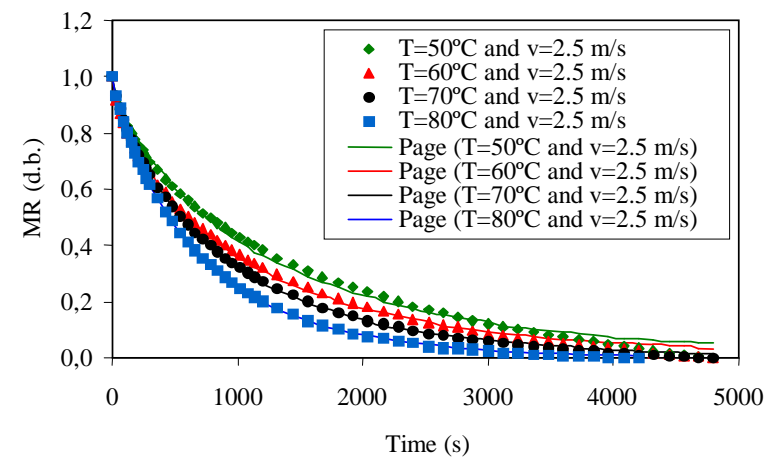

Figure 9 - Experimental and predicted dimensionless moisture of fish feed drying at airflow velocity of $2.5 \mathrm{~m} / \mathrm{s}$.

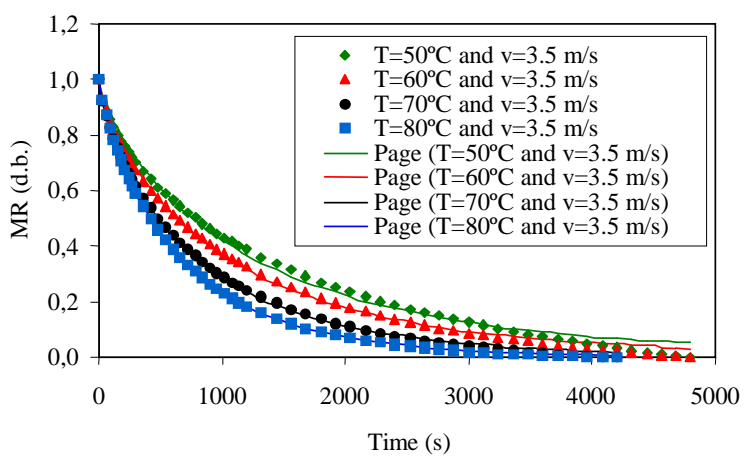

Figure 10 - Experimental and predicted dimensionless moisture of fish feed drying at airflow velocity of $3.5 \mathrm{~m} / \mathrm{s}$.

\section{Adsorption equilibrium isotherms of extruded \\ fish feed}

The mean experimental results of water activity $\left(\mathrm{a}_{\mathrm{w}}\right)$ and the respective equilibrium moisture values $\left(\mathrm{X}_{\mathrm{e}}\right)$ of extruded fish feed at $30,40,50$, and $70^{\circ} \mathrm{C}$ are shown in Table 2 and in Figure 11.
Table 2 and Figure 11 showed that the equilibrium moisture of the extruded fish feed had higher increase for water activity values between 0.597 and 0.834 . The air temperature influenced the equilibrium moisture of the feed, leading to an increase in the moisture adsorption. As such, the 
maximum value obtained was 0.20 (d.b.) at $30^{\circ} \mathrm{C}$, 0.695 (d.b.) at $40^{\circ} \mathrm{C}, 1.542$ (d.b.) at $50^{\circ} \mathrm{C}$, and at 2.3 (d.b.) at $70^{\circ} \mathrm{C}$. The great variation of the feed moisture showed that handling care was necessary, mainly in ambient with relative humidity of air higher than 0.6.
Figure 11 showed that the adsorption equilibrium isotherms of the feed had sigmoid form. This behavior is characteristic of food products, such as macaroni, flour, bread, cracker, egg albumin (Geankoplis, 1993), and chitin (Moraes et al., 2005).

Table 2 - Experimental equilibrium moisture $(\mathrm{Xe})$ for the different water activity values $\left(\mathrm{a}_{\mathrm{w}}\right)$ of feed at $30,40,50$ and $70^{\circ} \mathrm{C}$.

\begin{tabular}{ccccccccc}
\hline Saline solutions & $\mathbf{a}_{\mathbf{w}} \mathbf{3 0}^{\mathbf{}} \mathbf{C}$ & $\mathbf{X}_{\mathbf{e}} \mathbf{3 0}^{\mathbf{0}} \mathbf{C}$ & $\mathbf{a}_{\mathbf{w}} \mathbf{4 0}^{\circ} \mathbf{C}$ & $\mathbf{X}_{\mathbf{e}} \mathbf{4 0}^{\circ} \mathbf{C}$ & $\mathbf{a}_{\mathbf{w}} \mathbf{5 0}^{\circ} \mathbf{C}$ & $\mathbf{X}_{\mathbf{e}} \mathbf{5 0}^{\circ} \mathbf{C}$ & $\mathbf{a}_{\mathbf{w}} \mathbf{7 0}^{\circ} \mathbf{C}$ & $\mathbf{X}_{\mathbf{e}} \mathbf{7 0}^{\circ} \mathbf{C}$ \\
\hline $\mathrm{LiCl}$ & 0.113 & 0.000 & 0.112 & 0.000 & 0.111 & 0.009 & 0.109 & 0.000 \\
$\mathrm{CH}_{3} \mathrm{CO}_{2} \mathrm{~K}$ & 0.216 & 0.000 & 0.204 & 0.004 & 0.192 & 0.026 & 0.168 & 0.080 \\
$\mathrm{MgCl}_{2} 6 \mathrm{H}_{2} \mathrm{O}$ & 0.324 & 0.036 & 0.318 & 0.077 & 0.312 & 0.116 & 0.300 & 0.140 \\
$\mathrm{NaNO}_{2}$ & 0.635 & 0.039 & 0.616 & 0.079 & 0.597 & 0.122 & 0.559 & 0.250 \\
$\mathrm{NaCl}$ & 0.750 & 0.101 & 0.748 & 0.393 & 0.746 & 1.114 & 0.742 & 1.800 \\
$\mathrm{KCl}$ & 0.834 & 0.201 & 0.818 & 0.695 & 0.802 & 1.542 & 0.770 & 2.300 \\
\hline
\end{tabular}

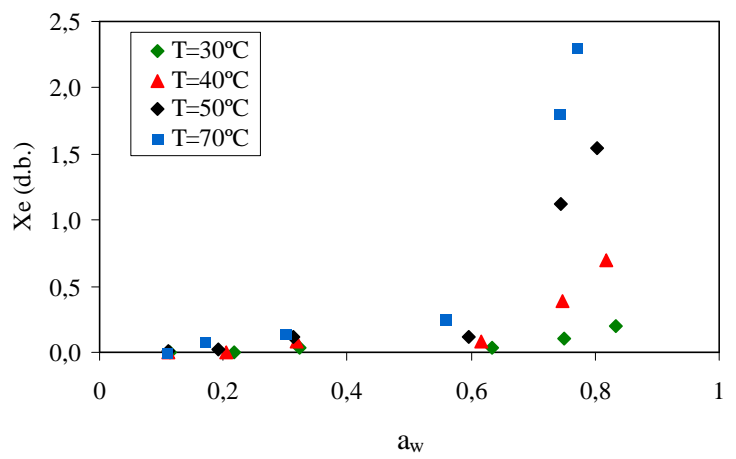

Figure 11 - Experimental adsorption isotherms of extruded fish feed at different temperatures.

Table 3 showed the estimated parameters for the models of Equations 9 to 11 and their respective statistical parameters $\left(\mathrm{R}^{2}, \mathrm{P}\right.$, and $\left.\mathrm{EE}\right)$ that were analyzed for the different drying conditions.

As observed in Table 3, the Peleg and HendersonThompson models showed satisfactory results according to statistical fitting parameters. However, the Peleg model stands out for its greatest $R^{2}$ and $F$ and lowest $\mathrm{P}$ values, being the most appropriate one to estimate the equilibrium moisture of extruded fish feed. The fitting results of this model are presented in Figure 12.

Table 3 - Estimated parameters of the models of the equilibrium isotherms of extruded fish feed.

\begin{tabular}{|c|c|c|c|c|c|c|c|c|}
\hline \multirow[t]{2}{*}{ Models } & \multirow{2}{*}{$\begin{array}{c}\begin{array}{c}\text { Drying } \\
\text { Conditions }\end{array} \\
\mathbf{T}\left({ }^{\circ} \mathbf{C}\right)\end{array}$} & \multicolumn{4}{|c|}{ Model Parameters } & \multicolumn{3}{|c|}{ Fitting Parameters } \\
\hline & & $a$ & $b$ & $c$ & $d$ & $\boldsymbol{R}^{2}$ & $\boldsymbol{F}$ & $P$ \\
\hline Peleg & 30 & 0.920 & 9.883 & 0.059 & 1.068 & 0.981 & 62.55 & 12.62 \\
\hline Peleg & 40 & 3.180 & 7.903 & 0.060 & 0.636 & 0.988 & 73.49 & 92.98 \\
\hline Peleg & 50 & 3.092 & 6.400 & 3.452 & 6.400 & 0.981 & 43.85 & 67.69 \\
\hline Peleg & 70 & 13.819 & 6.789 & -0.226 & 6.789 & 0.995 & 328.75 & 33.77 \\
\hline Henderson-Thompson & 30 & -0.096 & 0.387 & -337.904 & & 0.964 & 70.56 & 17.94 \\
\hline Henderson-Thompson & 40 & 0.350 & 0.326 & -307.689 & & 0.981 & 65.08 & 35.67 \\
\hline Henderson-Thompson & 50 & 0.100 & 0.333 & -309.307 & & 0.973 & 34.30 & 68.32 \\
\hline Henderson-Thompson & 70 & 0.100 & 0.288 & -331.625 & & 0.995 & 178.34 & 35.23 \\
\hline Keey & 30 & 90161.470 & 0.100 & & & 0.920 & 15.13 & 21.20 \\
\hline Keey & 40 & 366606.900 & 0.100 & & & 0.880 & 11.48 & 340.70 \\
\hline Keey & 50 & 1009593.00 & 0.100 & & & 0.860 & 9.26 & 419.07 \\
\hline Keey & 70 & 2075025.00 & 0.100 & & & 0.864 & 2.44 & 376.00 \\
\hline
\end{tabular}




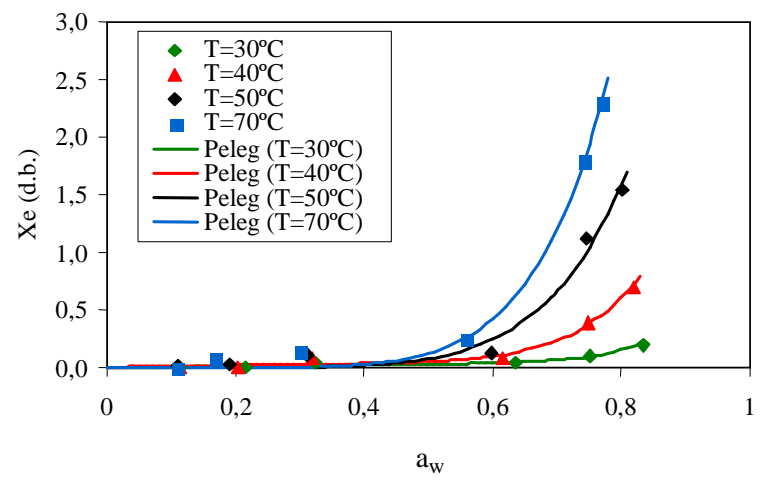

Figure 12 - Experimental and predicted adsorption isotherms of fish feed drying at different temperatures.

As shown in Figure 12, fitting equilibrium isotherms to the Peleg model also presented satisfactory results for Bartlett pear (Park et al., 2001), texturized soybean protein (Cassini, 2004) and dehydrated leaves of coriander (Lima et al., 2007).

\section{CONCLUSIONS}

The drying air temperature significantly affects the drying curves of extruded fish feed, while the effect of airflow velocity was limited.

The statistical analyses showed that the variation of the moisture content of extruded fish feed could be represented by the Page model which has been very efficient in the study of drying phenomena of several food products in the literature.

The equilibrium isotherms of extruded fish feed had sigmoid form, as has been frequently reported for food products in the literature.

The feed equilibrium isotherms were little influenced by air temperature variations for water activity values between 0 and 0.6 , but for water activity over 0.6 the equilibrium isotherms could reach 2.3 (d.b.) in the evaluated conditions.The fitting of the equilibrium isotherms of the feed to the Peleg model presented the best statistical results and proved to be the most suitable one to predict the equilibrium moisture of extruded fish feed.

\section{ACKNOWLEDGMENTS}

The authors thank the financial support by CAPES.

\section{REFERENCES}

Alexandre, H. F., Figueirêdo, R. M. F., Queiroz, A. J. M. (2007), Isotermas de adsorção de umidade da pitanga em pó. Rev. Biol. Ciênc. Terra, 7 (1),11-20.

Al-Ruqaie, I. M. (2007), Extruded leftover food as animal feed: I. Effect of extruded feed on growth and feed utilization of tilapia (Oreochromis niloticus) in Saudi Arabia. Pakistan J. Biol. Sci., 10 (19), 3248 3253.

Arnosti Jr, S. (1997), Desenvolvimento de um secador transportador do tipo esteira com escoamento cruzado e caracterização de sementes de gramíneas, MSc Thesis, PPGEQ/ Faculdade de Engenharia Química da UFSCAR, São Carlos - SP, 232p.

Ascheri, D. P. R., Guissoni, R. P., Moura, W. S. (2007), Isotermas e calor isostérico de adsorção de água de farinhas pré-gelatinizadas de bagaço de jabuticaba/arroz. Relatório Final de Projeto de Pesquisa, UEG, Anápolis, GO. Available in: http://www.prp.ueg.br/06v1/ctd/dstq/2007/ds_030520 07_02.pdf. Accessed on: 21/09/09.

Arruda, E. B. (2008), Comparação do desempenho do secador roto-fluidizado com o secador rotatório convencional: na secagem de fertilizantes. Tese de Doutorado, PPGEQ/ Universidade Federal de Uberlândia, Uberlândia - MG, 176p. 
Barrozo, M.A.S., Oliveira, D.T., Sancineti, G.P., Rodrigues, M.V. (2000), A study of the desorption isotherms of lentils. Braz. J. Chem. Eng., 17, 105109.

Botaro, D. (2007), Aqüicultura: grande aliada? Faces e Interfaces. Available in: http://www.olharvital.ufrj.br/2006/index.php?id_edic ao $=067 \&$ codigo $=4$. Accessed on: 10/06/09.

Brooker, D.B., Bakker-Arkema, F.W., Hall., C.W. (1992), Drying and Storage of grains and oilseeds. Westport: The AVI Publishing Company, 450p.

Cassini, A. S. (2004), Análise das características de secagem da proteína de soja. Dissertação de Mestrado, UFRS, Porto Alegre, RS, Brasil, 117 p. Available http://www.lume.ufrgs.br/handle/10183/4737. Accessed on: 18/09/09.

Corrêa, P. C., Machado, P. F., Andrade, E. T. (2001), Cinética de secagem e qualidade de grãos de milhopipoca. Ciên. Agrotéc., 25 (1), 134-142.

Corrêa, P. C., Resende, O., Martinazzo, A. P., Goneli, A.L.D., Botelho, F. M. (2007), Modelagem matmática para a descrição do processo de secagem do feijão (Phaseolus vulgaris L.) em camadas delgadas. Eng. Agríc. Jaboticabal, 27 (2), 501-510.

El-Sayed, A. F. M. (1999), Alternative dietary protein sources for farmed tilapia, Oreochromis niloticus. Aquac. Res., 179, 149 -168.

FAPEAM, (2009), Fábrica de ração estimula a produção de peixes em cativeiro. Available in: http://midiaemeioambiente.blogspot.com/2008/02/fbr ica-de-rao-estimula-produo-de-peixes.html. Accessed on: 29/06/2009.

Fadini, A. L., Silva, P. M. P., Jardim, D. C. P., Vissoto, F. Z., Queiroz, M. B. Batista, G. (2006), Isotermas de sorção de umidade e estudo de estabilidade de macadâmias drageadas. Braz. J. Food Technol., 9 (2), $83-88$.

Faria, A.C. E. A., Hayashi, C., Galdioli, E. M., Soares, C. M., (2001a), Farinha de peixe em rações para alevinos de tilápia do Nilo, Oreochromis niloticus (L.), linhagem tailandesa. Acta Scient., 23 (4), 903 908.

Faria, A.C. E. A., Hayashi, C., Soares, C. M. (2001b), Substituição parcial e total da farinha de peixe pelo farelo de soja em dietas para alevinos de piavuçu (Leporinus macrocephalus). Acta Scient., 4, 835-840.

Geankoplis, C. J. (1993), Transport processes and unit operations. Prentice-Hall International Editions, New Jersey, 921p.

Gomes, P. M. A., Figueiredo, R. M. F., Queiroz, A. J. M. (2002), Caracterização e Isotermas de adsorção de umidade da polpa d acerola em pó. Rev. Bras. Prod. Agroind., 4 (2), 157-165.
Guedes, A. M. M., Faria, L. J. G. (2000), Determinação da constante de secagem de urucum (Bixa orellana L.) em secador convectivo de leito fixo. Rev. Bras. Prod. Agroind., 2 (1), 73-86.

Karathanos, V. T., Kanellopoulos, N. K., Belessiotis, V. G. (1996), Development of Porous Structure during Airdrying of Agricultural Plant Products, J. Food Eng., 29, 167-183.

Keey, R. B. (1991), Drying of loose and particulate materials. Hemisphere Publishing.

Kubitza, F. (1995), Preparo de rações e estratégias de alimentação no cultivo intensivo de peixes carnívoros. Trabalho apresentado no Simpósio Internacional sobre Nutrição de Peixes e Crustáceos. Campos do Jordão, Campos de Jordão, Sâo Paulo, p.91-109.

Kubitza, F. (1997), Principais alimentos e suas restrições para peixes. In: Nutrição e alimentação dos peixes. Piracicaba, Ed. da Escola Superior de Agricultura Luiz de Queiroz. 74p.

Lima, E. E., Silva, A. S., Melo, K. S., Alves, N.M.C., Dantas, H.J. (2007), Utilização de modelos matemáticos para estimar as isotermas de adsorção de folhas desidratadas do coentro. Trabalho apresentado na II Jornada Nacional da Agroindústria, Bananeiras, Pernambuco.

Luz, G. R., Sousa, L. H. C. D., Jorge, L. M. M., Paraíso, P. R. (2006), Estudo das isotermas de equilíbrio do farelo de soja. SBCTA, 26 (2), $408-$ 413.

Luz, G. R., Pereira, N. C., Jorge, L. M. M., Andrade, C.M.G., Paraíso, P.R. (2009), Mass transfer coefficient in soybean meal drying. Braz. J. Food Technol., 12 (2), p. 92-96.

Magliano, R., (2007), Aqüicultura: grande aliada? Faces e Interfaces. Available in: http://www.olharvital.ufrj.br/2006/index.php?id_edic $\mathrm{ao}=067 \&$ codigo $=4$. Accessed on: 10/06/09.

Moraes, M. A., Rosa, G. S., Pinto, L. A. A. (2005), Estudo das isotermas de equilíbrio para quitina: determinação do calor de dessorção. Trabalho apresentado nos Anais do VI Congresso Brasileiro de Engenharia Química em Iniciação Científica, Campinas, São Paulo(publicado em CD-ROM).

Mrkic, V., Ukrainczyk, M., Tripalo, B. (2007), Applicability of moisture transfer $B i-D i$ correlation for convective drying of broccoli. J. Food Eng., 79, 640-646.

Mujumdar, A. S. (1987), Handbook of industrial drying. Marcel Dekker, Inc., New York.

Page, C. (1949), Factors Influencing the maximum rate of drying shelled corn in layers. MSc Thesis, West Lafayette, Purdue University. 
Park, K. J., Bin, A., Brod, F.P.R. (2001), Obtenção das isotermas de sorção e modelagem matemática para a pêra Bartlett (Pyrus sp.) com e sem desidratação osmótica. SBCTA, 21 (1), 73-77.

Peleg, M. (1993), Assessment of a semi-empirical four parameter general model for sigmoid moisture sorption isotherms. J. Food Proc. Eng., 16 (1), 21-37.

Perry, R.H., Chilton, C.H., (1980), Manual de Engenharia Química. Guanabara Dois S.A., Rio de Janeiro, 1250p.

Santosi, I. J., Couto, S. M., Andrade, E.T. (2001), Cinética de Secagem em Camada Fina do Malte Verde de Cevada. Rev. Bras. Prod. Agroind., 3 (1), p.53-59.

Souza, R. S., Hayashi, C. (2003), Avaliação do farelo de algodão na alimentação de alevinos de tilápia do Nilo (Oreochromis niloticus L.). Zoot. Trop., 21 (4), $383-398$.
Sussel, F. R. Alimentação na criação de peixes em tanques-rede. (2008), Available in: ftp://ftp.sp.gov.br/ftppesca/alimentacao_peixes.pdf. Acessed on: 10/03/08.

Teixeira, E. N. M., Silva, J. H. V., Costa, F. G. P., Ribeiro, M. L. G., Araujo, D. M., Jordão Filho, J. (2007), Inclusão do ovo desidratado em rações peletizadas ou fareladas para frangos de corte. Rev. Bras. Zoot., 36 (5), 1372 - 1381.

Thompson, T. L; Peart, R. M.; Foster, G. H. (1968), Mathematical simulation of corn drying - A new model. Transaction of the ASAE, St. Joseph, 11 (4), 582-586,.

Wang, C. Y., Singh, R. P. (1978), Use of variable equilibrium moisture content in modeling rice drying. ASAE Paper, p. 78-6505, ASAE, St. Joseph-MI.

Received: December 10, 2009; Revised: August 18, 2010; Accepted: February 28, 2011 